3. Diachenko, Yu. (2002). The international and national in modern design. Visnyk Kharkivskoi derzhavnoi akademii dyzainu i mystetstv [Bulletin of the Kharkiv State Academy of Design and Arts], no. 6, pp. 248-250.

4. Lozko, H. (2006). Ukrainian ethnography. Kyiv: ArtEK.

5. Peretokin, A. (2016). Traditional Ukrainian manor at the end of the 19th - the beginning of the 20th century. Visnyk Prydniprovskoi derzhavnoi akademii budivnytstva ta arkhitektury [Bulletin of the Prydneprovsk State Academy of Construction and Architecture], no. 7 (220), pp. 45-54.

6. Perez, O. (2006). Humanization of the contemporary subject-spatial environment of Ukrainian regions with artistic signs of traditional aesthetics. Visnyk Kharkivskoi derzhavnoi akademii dyzainu i mystetstv. Mystetstvoznavstvo. Arkhytektura [Bulletin of the Kharkov State Academy of Design and Arts. Art Criticism. Architecture], no. 5, pp. 43-56.

7. Ponomariov, A. (1993). The Ukrainian past: An illustrated ethnographic directory. Kyiv: Lybid.

8. Shcherbakivskyi, V. (1980). Ornamentation of a Ukrainian Hut. Rome.

9. Yurchenko, P. (1941). People's Home of Ukraine. Moscow.

(C) Оборська С. В., 2018

УДК 008 : 312.421

Пономаренко Юрій Володимирович, аспірант,

Київський національний університет культури і мистецтв, Київ, Украӥна, ponomarenhoyura@i.ua

\title{
ГАРМОНІЯ В СУЧАСНІЙ ХОРЕОГРАФІЇ
}

Мета дослідження - визначити формотворчі тенденції еволюції хореографії (домінанти експресивних видів мистецтв) як фактор гармонізації глобалізаційних проблем сучасності. Методи дослідження. У роботі над дослідженням використовувалися методи аналізу, синтезу, порівняння, узагальнення. Наукова новизна. Вперше хореографія розглядається в контексті хореїчного комплексу сучасної культури як новітньої форми синкретизму та синтезу мистецтв. Аналізуються провідні видовищні форми сценізму танцю як актуальної програмної вистави. Висновки. Досліджено, що хореїчність, хореографічність, експресивний вимір - це ті настанови, які є системотворчими в сучасній культурі, де арт-практики рефлектують досвід кінесики танцю та інтерпретують його як внутрішній стрижень формотворення. Виявлено, що досвід вивчення хореографічної культури пов'язаний 3 культурно-історичною реконструкцією систем нотації танцю як сукупності писемних практик хореїчної реальності культури в цілому. Проаналізовано, що система нотації танцю як певний код переведення динаміків в графематику, 
а також своєрідна палеографія танцю дає надзвичайно багато, щоб зрозуміти як гармонія руху перетворюється в певний візуальний простір презентації експресивних видів мистецтв.

Ключові слова: культура, хорея, хореографія, танок.

Пономаренко Юрий Владимирович, аспирант, Киевский национальный университет культури и искусств, Киев, Украина

\section{Гармония в современной хореографии}

Цель исследования - определить формообразующие тенденции эволюции хореографии (доминанты экспрессивных видов искусств) как фактор гармонизации глобализационных проблем современности. Методы исследования. В работе над исследованием использовались методы анализа, синтеза, сравнения, обобщения. Научная новизна. Впервые хореография рассматривается в контексте хореического комплекса современной культуры как новейшая форма синкретизма и синтеза искусств. Анализируются ведущие зрелищные формы сценизма танца как актуального программного представления. Выводы. Доказано, что хореичность, хореографичность, экспрессивное измерение - это те установки, которые являются системообразующими в современной культуре, где арт-практики рефлектируют опыт кинесики и интерпретируют его как внутренний стержень формообразования. Выявлено, что опыт изучения хореографической культуры связан с культурноисторической реконструкцией систем нотации танца как совокупности письменных практик хореичной реальности культуры в целом. Проанализировано, что система нотации танца как некий код перевода динамиков в графематику, а также своеобразная палеография танца дает очень много, чтобы понять, как гармония движения превращается в определенное визуальное пространство презентации экспрессивных видов искусств.

Ключевые слова: культура, хорея, хореография, танец.

Ponomarenko Yuriy, postgraduate, Kiev National University of Culture and Arts, Kyiv, Ukraine

\section{Harmony in modern choreography}

The aim of the research is to determine the system-forming tendencies in the evolution of choreography (dominant of the expressive arts) as a factor in harmonizing the globalization problems of our time. Methodology of the research. In the work on the study methods of analysis, synthesis, comparison, generalization were used. Scientific novelty. For the first time choreography is studied in the context of the choreical complex of modern culture as the newest forms of syncretism and the synthesis of arts. The leading spectacular forms of dance thesis as an actual program presentation are analyzed. Conclusions. It is proved that trochaicity, choreography, expressive measurement are those settings that are system-forming in modern culture, where art practices reflect the experience of kinesics so it is interpreted as an internal core of form formation. It is revealed that the experience of studying choreographic culture is associated with the cultural and historical reconstruction of the dance notation systems as a set of written practices of the 
trochaic reality of culture as a whole. It is analyzed that the system of notation of dance as a code for transferring speakers to graphematics, as well as a peculiar palaeography of dance, gives a lot to understand how the harmony of movement turns into a certain visual space for the presentation of expressive arts.

Key words: culture, trochaicity, choreography, dance.

Вступ. Розвиток експресивних видів мистецтв (танок, музика, театр, поезія тощо) свідчить про тенденції до синтезу, певне «повернення» до хореїчного синкретизму. Актуальним є визначити хореографічне мистецтво, як домінанту такого синтезу. Танець у його інституалізованому виді як певна культурна практика (хореографія), як і в Давній Греції, домінує в синтезі експресивних мистецтв, що має особливе вираження в його візуальних артефактах. Наукова проблема, яка розглядається в статті полягає в тому, щоб реконструювати хореографію як культурно-історичну цілісність 3 присутньою для неї системою нотації (фіксації часу й простору образної динаміки танцю). Ключовими поняттями є «хорея» як єдність експресивних та конструктивних видів мистецтв, «культурна практика» як інституалізована культурна реальність видів мистецтв, що входять у хореїчний комплекс, «танок» як сакралізована реальність ритмопластики, на відміну від «танцю» в загальному понятті. Саме танок у системі хореографії кін. ХX ст. $\epsilon$ актуальним як відродження синтетичних тенденцій формування новітнього комплексу експресивних мистецтв.

Метою дослідження $€$ визначення формотворчих тенденцій еволюції експресивних видів мистецтв як фактору гармонізації глобалізаційних проблем сучасності. Об'єктом наукового дослідження $є$ єдність експресивних видів мистецтв у сучасній культурі, предметом наукового дослідження $€$ хореографічний синтез мистецтв як домінанта сценічного простору сучасної культури.

Виклад основного матеріалу. Експресивні види мистецтв у сучасній мистецтвознавчій та театрознавчій, естетичній рефлексії аналізуються окремо, як окремі види мистецьких практик сучасного сценізму культури. Втім, важливо визначити синтетичні (хореїчні) витоки актуалізації культурноісторичного потенціалу мистецтва як певного мета художнього та мета культурного синтезу мистецтв.

Танок як найдавніший вид культури продовжує існувати в постмодерні і визначається тими глибинними трансформаціями фундаментальних образів, уявлень культури, які формуються в танці. Танок стає своєрідним архівом культуротворчих інтенцій, має образи, маркери тих образних конфігурацій, які приходять, нашаровуються, формуються в просторі сценізму того чи ін. твору.

Синтез мистецтв, як данина культурі, починається 3 експресивних мистецтв, які в давні часи утворюються за домінантою танку. Ритмічна формотворча імпульсивність танку, звичайно, дає можливість визначення тих конфігурації, які нині потребують свого здійснення в ін. арт-конфігураціях. Тобто, можна зазначити граматику танцю, що сформувалася ще в часи Середньовіччя, а потім були розвинуті в Новому та Новітньому часі. Сьогодні 


вони $\epsilon$ своєрідними архітектурними строями ритмологічного,
ритмопластичного світу хореографії. Такі механізми побудови танку, як аритмія, ритмічна цілісність, конкретність ритму, ритмологія, ритмопластика, ритмобуття, формування ритму дають можливість розгорнуть його в певних культурних артефактах, які нагадують орнамент фрески, рельєфи у візуальному просторі сучасних інсталяцій, що дають можливість визначення різких контрпозицій сучасної культури. Синтез артефактів сучасної культури походить від триєдиної хореї як синкретичної єдності танцю, музики, співу, де графематика, запис, нотація руху, піктографізація як певна дискретизація руху та його пластичних еквівалентів, що занотовані, дають можливість записати його експресивну архітектоніку.

Описуючи становлення хореографічної культури у сезонах Дягілєва, В. Гаєвський пише: «І цей образ - незахищеної художньої геніальності супроводжував Фокіна 3 перших його кроків, і в «Лебіді», і в «Шопеніані», і в «Петрушці». До цього образу Фокін повертається в одному із останніх (1939 рік) балетів - «Паганіні». Саме тут його заповіт, виклик долі, саме тут горісні роздуми. А може бути Фокін так і вважав: художня геніальність і повинна бути - або виглядати - беззахисною. На то вона і геніальність. I класичний танок, 3 котрим Фокін все життя ворожнечів, але котрий час від часу оспівував, був прекрасним тоді, коли був незахищеним - ні технічною віртуозністю, ні виворотністю, ні жорстким академічним каркасом» [3, с.34].

Такі балерини класичного типу, як Тамара Карсавіна та «босоніжка» Асейдора Дункан намагалися осмислить широкий контекст трансформації танцю у ХХ столітті. Ці автори власних рефлективних екзерзисів з різних позицій говорять про одне - системотворчу роль ритму, пластики як архетипів культури в цілому. Так, Т. Карсавіна пише: «Пізніше, в Парижі, я дивилась на Айседору вже більш критичним поглядом. Там вона викладала свої теорії і поясняла сутність свого мистецтва. Я не могла вже розглядувати іiі лише як художника з яскраво вираженою індивідуальністю» [5, с. 155].

Сергій Худеков - ділетант в історії хореографічної культури захоплювався балетом і написав неперевершену історію балету кін. XIX - поч. ХХ ст. Його візаві - коди хореографічної ідентичності танцю всіх культур і народів - архітектонічність, пластичність, ритмічність, експресія. Ці виміри хореографічної культури зараз існують в контексті різних самовизначень постмодерністськіх шкіл танцю.

С. Худеков пише: «Артисток, що займалися відтворенням античних танців, можна поділити на дві категорії - одна 3 них відрізнялась урівновішеними, повільними темпами і жестами. Вони приймали пози, копіюючи красиві античні статуї. Інші ж присвячували свій талант виключно оргіастичним танкам» [8, с. 219].

Евритмія має на меті визначення ритму як певного хронону, де простір і час презентуються як пластика, силует, архітектоніка, зображення, ієрогліф, фіксація, нотація. Все це дає можливість охарактеризувати танок, який здійснюється «тут» і «зараз», на цій сцені як танок універсальний, як простір саморуху буття хореїчного образу. Танок як тілесне кінетичне буття людини 
переводить модальності візуальних образів у внутрішній ритмологічний простір культури, ніби «протанцьовує» всю віртуально-візуальну культуру. Танок поєднує макро- і мікро-косм, і власне тіло людини, що танцює на сцені, танцює в модальностях образних імплікацій, синергії, синестезії. Танцює так, що ми не помічаємо часу, і лише своєрідна нотація, фіксування часу й простору конфігурацій тілесних імплікацій залишаються в пам’яті. Додамо, що відеозапис теж своєрідна система нотації руху, віртуально зрежисованого на екрані.

Важливо зазначити, що такий образ хореїчності виводить поняття «хореографія» за межі сценічного простору. А 3 іншого боку, навпаки, розширює категорію сцени до комунікативного простору, де візуальний поворот робить іiі надзвичайно експансивно-драматичним концептом. Цей концепт намагаються осмислити дуже багато послідовників. Відтак, якщо говорити про будь-які радикальні ритмології в експресивних видах мистецтв, особливо сучасних видах мистецтв, то, звичайно, треба окреслити обрій, горизонт культурологічної інтерпретації.

Теорія відмінювання історичних форм А. Тойнбі, викладена в його роботі «Осягнені історії», де він говорить, що найбільш конструктивним принципом культуротворення є трансформація дії як евристичний поштовх інтерпретації: „Найбільш конструктивним принципом є трансференція дії. Щоб феномен трансференції дії мав місце, необхідне, щоб індивідуальні або колективні біографії, в котрих буде здійсненний творчий акт відповіді на кинутий виклик, здійснювалися як аналог такої трансференції. I цим реальним аналогом є рух уходу i наступного повернення. Ухід i повернення можна, таким чином, розглядати як двохактний ритм творчих актів, що здійснює процес зростання” [7, с. 261]. Щоб феномен трансформації дії мав місце, необхідні індивідуальні або колективні події, котрими буде здійснена творчий акт як відповідь на виклик.

Цілісною фазою дієвої трансформації культури є рух уходу і наступного повернення. Ухід і повернення можна розглядати як двохактний ритм творчих актів, що здійснює процеси зростання його ступенів свободи. Втім, ця бінарна, дихотомічна система хронотопу культуротворення визначає переддію і післядію, а власне сам процес події, зокрема танку не помічається. Отже, виклик і відповідь, рух і спокій, час і простір є своєрідними детермінантами віртуальної реальності танку, яку можна побачити, зчитати з фресок печер Аджарти, так побачити у сьогоднішніх реаліях інтерпретації танку у сучасних системах хореографії.

Хорея залишається в межах театральних систем хореографічної майстерності як певний інструментарій підживлення мистецтва танцю. Культурний і образний контексті тих чи інших реформаторів хореографії, якими були М. Бежар, А. Петі, Р. Нурієв, був побудований як образ відходу і повернення, образ часу, що утворює реальність абетки, алфавіту танцю, яка запозичується в цих майстрів 3 грецької культури, класицизму, модерну. Виникає монтаж атракціонів, гострих пластичних екзерсисів, хореографічних систем, які сформувалися в культурі XX ст. Так чи інакше, категорія «ритм» стає наскрізним системотворчим фактором пульсації часу і простору, а власна метрика, система вимірювання часу та просторових реалій, визначених 
уграфематиці, пластиці, архітектоніці, дає можливість зазначити, що відбувається певне чергування візуальних картин, мізансцен, чергування відходу й повернення.

Д. Баланчін перевтілює модерн у неокласику і до кінця свого життя зберігає цей образ у танку. В. Ніжинський привніс у хореографію кінематографічні елементи, монтаж, своєрідне повернення до Єгипту. Відбувається гостра трансформація кінематики, фасадних i бокових конфігурацій тіла, a їх сценічна розкадровка дає можливість застосування більш архаїчних, орієнтованих на магію, ритуал, міф, інспірацій тих великих нормативів нотацій записів руху, які шукають свої нарації у визначенні хореїчного простору постсучасності.

Починаючи 3 класицистської хореографії XVII ст. Людовіка XIV та закінчуючи постмодерною хореографію, відбувається своєрідний категоріальний синтез космологізму та індивідуальної виразності хореїчності як глибинних фундаментальних настанов танку. Симбіоз, цілісність, пластичність, ритмологічність - це ті категорії, які говорять, що категорія танцю є одною із гармонізуючих, домінантних реалій сьогоднішнього бачення культури в цілому як організму тілесного антропоморфного простору. Рушійний простір дискритизується в рефлексії, в ньому знаходяться траекторія динаміки, пластичні зони, епіцентри динаміки і спокою. Таким чином, архітектонічна цілісність рушійного, динамічного тіла людини створює певну тотальність порядку культури і порядку всесвіту.

Отже, в середині XX століття людина починає тяжіти до нотації власної динаміки не лише в танку, а й інших видів мистецтва, але танок стає тою метамовою, де мова міміки, пантоміми, силуету стає засадою утворення тих конфігурацій, які ми бачимо у блискучих чорно-білих стрічках кінематографу. Н. Віхрєва надає детальний аналіз системи нотації танцю [2]. Зображення дає експресивний простір, який потім переходить в систему вже новітніх, віртуальних, дизайнерських знахідок, до школи Швейцарського графічного дизайну, зокрема. Танок лежить в основі тої жестуальної драматургії, що орнаменталізує все сутнє, свідчить про орнамент всього сутнього, який здійснюється і в XXI столітті, і в неоліті, і в палеоліті.

Важливо зазначити певний синкретизм хореографічної або хореїчної логіки танку. Танок вписується в певні жанри, формати, конфігурації - балет, оперу, естраду тощо. А. Ахутін пише: «Мусічне утворення робить саму людину малим устроєм (мікрокосмосом), здібним налавштуватися на устрій світу в цілому, тілом, душею, розумом увійти в цей стрій, як учасник хору входить у загальний танок. Існування людини набуває строю, космічності: світоподібного єтосу, ритму додільності і своєчасності, форми відповідно потрібного і непотрібного» [1, с. 298].

Танок робить мусічні мистецтва психологічно ритуальними, міфологічними, магічними, імагінативними як простір хореїчної ритмопластики, орнаментталізації світу, що відбуваються, зокрема в постмодернізмі, де сама орнаментальність стає найголовнішим принципом бачення і структурування світу. Як у класичній культурі, в культурі молодіжній (хіп-хоп), культурі 
етнозангажованій, в реконструкціях втрачених мотивів танку, хоре-діях, в хореспівах, в хореї як глибинному фундаментальному космологічному устрої утворюється комунікативна єдність людей як ритмічно-танцювальний образ, сутність якого полягає в імагінативній орнаментації часу і простору. Тобто, космологічна єдність має наскрізну інтуїцію хореїчної культури в цілому.

Хореографія Відродження, бароко, помпезність кінських балетів, величезних видовищ 3 каруселями свідчить про те що, хореографія, дивертисменти як видовищні субструктури були монументальним величезним простором, який раптом стискується, позбавляється широкої графематики і синтагматики площі, починає жити, як в печері, достатньо вузькому і структурованому просценіумі. Просценіум - це своєрідна вертикалізація сцени, межа сцени, де обрив вниз хореїчної ями, вихід на глядача завжди говорить про межовість того комунікативного простору, який визначається як сценічна вигородка або сценічна реальність піднятого помосту над образом буденності.

Сцена як поміст, піднятий над землею, переутворюється у комунікативні строї рефлексії хореографа вже не піднятої над світом, а зануреної у пристрасті хаосогенного середовища. Втім, цей стрій має бути осмислений як культуровимірний простір. Тобто відбувається рух від синкрез хореографічної культури до синтезу, від міфологізації до індивідуації танцю. Це той концептуальний простір, який формується у поетиці танку В. Ніжинського, Д. Баланчина, С. Ліфаря і ранніх танцювальних екзерсисах XX століття. Важливо зазначити міфогенез, хореїчність як глибинні імпульси своєрідного неодіонісизму, ескалація пристрастей, що походить від Давньої Греції, адже було помічено сучасними хореографами як певний фактор виховання смаку.

Отже, можна стверджувати, що експресивні види мистецтва, a їх квінтесенція - хореореографія - це внутрішній симбіоз слова та дії, пластичної, візуальної експресії. Все це можна визначити як своєрідне структурування естетичної реальності.

Наукова новизна. Вперше практики культури досліджується як єдина культурна практика у контексті глобалізаційних процесів культуротворчості. Феноменологічні, естетичні, сакральні виміри культуротворення визначаються як чинники гуманізації культури повсякдення та як певні субкультури, що стають антиглобалізаційними чинниками у сучасному цивілізаційному просторі.

Висновки. Динаміка танку, яку потрібно інтерпретувати як метафізичну універсалію культури, структурує ті конфігурації культуротворчості, які можна визначити як ритмологію. Тобто, рушійний і водночас пластично-динамічний простір пересування, мандрування, а також статики, фіксації зображень, конфігурацій та тілесних презентацій свідчить про орнаментальність всього сутнього. Реципієнт виходить за межі сцени «тут» i «зараз», формується багатопланова, поліфонічна структура хореїчного виміру реальності, де триєдність танцю, музики й поезії здійснює ту аритмію, або ритмологічну цілісність образу, яка потім розкладається на структурну диференціацію системи пластичних, візуальних адеквацій рефлексії хореографа, що пов'язують з граматикою танцю, його нотацією, фіксуванням зображень руху 
на сцені. Це може бути просто відеозапис, може бути нотація, яку здійснював той же А. Бурдель, коли змальовував танок А. Дункан у вигляді експресивних пульсуючих силуетів, які можна побачити в його скульптурах на фасаді театру на Єлисейських полях. До речі, А. Дункан залишила свої спогади, які можна сприймати як певний проект формування танку майбутнього [4]. Г. Крег писав: «Іїі називали великим митцем, грецькою богинею, але нічим подібним вона не була.» [6, с.159].

Асейдора Дункан намагалася досягти космологічності танку і фактично тому вона залишиться одним із цікавих реформаторів хореографії XX ст. Якщо пунктирно зазначити системи хореографії, які виникають на поч. XX ст., а потім вже формуються постмодерні хореографії, то це переважно рефлексія хореографів. Г. Баланчин - один із цікавих неокласиків - не був таким ортодоксальним, як В. Ніжинський, який підхопив кубізм поетик А. Гльоза і Ж. Метценж'є та намагався ввести їх в реалії класичного мистецтва танку. Образ танку, який він створював, був своєрідною інсталяцію одвічної гармонії.

Більш пізня хореографія, зокрема, балети в певній мірі вже розхитують поетику класичному типу. Такі балети, як «Пікова дама» А. Петі, перетворюються на своєрідний полістилістичний напрям. Культ масовості серединного рівня, вуличної повсякденності набуває своєрідної екзальтованої реальності. Традиціоналіський пафос вистав М. Бежара тяжіє до філософських, культурологічних інтерпретацій фольклору, які так чи інакше, межують 3 гламуром і треш-культурою. Кітч розуміється не просто як межа між життям і смертю, яка розмивається і зсувається в потоці балетних екзерсисів, виникає візерунок, ритмологічна аретея, яка усуває все за межі масової культури.

Бежар мав стосунки 3 «Гранд опера», Петі створює свій театр. Його запрошують очолювати Паризьку оперу, але він спочатку запропонував спалити «Гранд опера», знищити всю ієрархічну структуру трупи, на якій тримається система балетної ієрархії. У власних балетних екзерсисах Петі формує виміри наскрізного потоку, дифузного культуротворчого нонконформізму, що в європейському просторі поєднує культуру хіпі, панків, діалектику зустрічі класичної культури батьків і протестної культури дітей. Це контркультура, естетичний культ наркотиків, алкоголю, гомосексуалізму, знищення моральних табу. Хореографія А. Петі заперечує традиційну граматику танцю, але це також й неокласика, де контркультура хіпі, до яких приєднується відомий модельєр Ів сен Лоран, входить до широкого простору експресивного кітчевого виміру культуротворчості.

Отже, неокласицизм, постмодерна поетика в хореографії кін. ХX ст. поєднуються на підставі всезагальної аритмології, гіпертрофії часу, виходу в небачені раніше просторові масштаби.

Перспективи подальших досліджень полягають у пошуку новітніх перспектив актуалізації хореїчного синкретизму мистецтв як засадничого принципу формування новітніх мистецьких синтез у сценічному мистецтв 


\section{Список використаних джерел}

1. Ахутин А. В. Античные начала философии / А. В. Ахутин. - СанктПетербург : Наука, 2007. - 784 с.

2. Вихрева Н. А. Сохранение и реконструкция авторской хореографи : методы фиксации и расшифровки : дис... на соискание науч. степени канд. искусствовеления: 17.00.01 / Надежда Алексеевна Вихрева; Рос. акад. театрального искусства. - Москва, 2008. - 269 с.

3. Гаевский В. Хореографические портреты / В. Гаевский. - Москва : Артист. Режисер. Театр, 2008. - 606 с.

4. Дункан А. Танец будущого ; пер. с нем. под ред. Я. Мацкевича / А. Дункан. Москва : Заря, 1908. - 31 с.

5. Карсавина Т. П. Театральная улица / Т. П. Карсавина. - Ленинград : Искусство, 1972. -248 с.

6. Крэг Э. Г. Воспоминания. Статьи. Письма / Э. Г. Крэг. - Москва: Искусство, 1988. $-399 \mathrm{c}$.

7. Тойнби А. Постижение истории / А. Тойнби. - Москва: Прогресс, 1991. $731 \mathrm{c}$.

8. Худеков С. Н. История танцев. В. 4. ч. Ч. 1. / С. Н. Худеков. - СанктПетербург : Тип. «Петербургской газеты» Петербург, 1913. - 309 с

\section{References}

1. Akhutin, A.V. (2007). Ancient principles of philosophy. St. Petersburg : Nauka.

2. Vikhreva, N.A. (2008). Preservation and reconstruction of the author's choreography: methods of fixing and decoding. D.Ed. Russian Academy of Theater Arts.

3. Gaevskii, V. (2008). Choreographic Portraits. Moscow: Artist. Rezhiser. Teatr.

4. Dunkan, A. (1989). The Dance of the future. Moscow: Zarya.

5. Karsavina, T.P. (1972). Theatrical street. Leningrad: Iskusstvo.

6. Kreg, E.G. (1988). Memories. Articles. Letters. Moscow: Iskusstvo.

7. Toynbi, A. (1991). Comprehension of history. Moscow: Progress.

8. Khudekov, S.N. (1913). The history of the dances. In part 4. part. 1. St. Petersburg: Printing house of St. Petersburg newspaper «Petersburg».

(C) Пономаренко Ю. В., 2018 